Bensing, J., Dulmen, S. van, Kallerup, H., Visser, A., Borrell, F., Finset, A., Goedhuys, J., Langewitz, W., Mallinson, C., Peltenburg, M., Schofield, T., Zimmermann, C. The European Association for Communication in Healthcare. Patient Education and Counseling: 2001, 43(1), 4

\begin{tabular}{|c|c|}
\hline $\begin{array}{l}\text { Postprint } \\
\text { Version }\end{array}$ & 1.0 \\
\hline Journal website & http://dx.doi.org/doi:10.1016/S0738-3991(01)00125-2 \\
\hline Pubmed link & http://www.ncbi.nlm.nih.gov/pubmed/11311833 \\
\hline DOI & $10.1016 / \mathrm{S} 0738-3991(01) 00125-2$ \\
\hline
\end{tabular}

This is a NIVEL certified Post Print, more info at http://www.nivel.eu

\title{
The European Association for Communication in Healthcare
}

\author{
JOZIEN BENSING', SANDRA VAN DULMEN, HANS KALLERUP, ADRIAAN VisSER, FRANCESC \\ BORRELL, ARNSTEIN FINSET, JO GOEDHUYS, WOLF LANGEWITZ, CHRIS MALLINSON, \\ Michael PeltenbURG, THEO SCHOFIELD AND CHRISTA ZiMMERMANN
}

\begin{abstract}
1. INTRODUCTION
In September 2000 a special meeting was called during the International Conference on Health and Communication in Barcelona to launch a new European association [1]. The name of the association is EACH: The European Association for Communication in Healthcare. In January 2001, the first formal board meeting took place in The Netherlands. During this meeting, thirteen researchers, medical educators and practitioners from eight European countries met in Utrecht to discuss the objectives and the provisional agenda for the first two years.
\end{abstract}

\section{A MULTIDISCIPLINARY ASSOCIATION}

The founding members of EACH recognise the importance to establish a multidisciplinary society that is meant for all health care providers (e.g. doctors, nurses, physiotherapists) and social scientists (e.g. psychologists, sociologists, anthropologists, linguists) who are active in communication research and/or training, and who are willing to exchange their ideas, expertise and research findings with colleagues all over Europe. Nowadays, it has become generally acknowledged that, in addition to evidence-based medical-technical procedures, communication in health care has a profound impact on health delivery, patients' health, well-being, self-management capabilities and outcome.

Besides, provider-patient interaction is changing from a paternalistic, provider-centered approach into a more co-operative, patient-centered and relationship-centered [2] approach, aimed at shared responsibility and shared decision-making. Important new concepts such as patient autonomy and empowerment ask for another communication style focused at dialogue and negotiation [ 3 and 4]. To comply with these changing needs, the quality of health care is likely to benefit from a close cooperation between educators and researchers. Such an alliance will contribute to enhancing knowledge about effective communication, establishing best practices and improving education [5].

\section{EUROPEAN EXPERIENCE}

Realizing the nature of the patient's health problem, providing information and advice, enhancing patient's competence and relieving patient's suffering are the most important 
Bensing, J., Dulmen, S. van, Kallerup, H., Visser, A., Borrell, F., Finset, A., Goedhuys, J., Langewitz, W., Mallinson, C., Peltenburg, M., Schofield, T., Zimmermann, C. The European Association for Communication in Healthcare. Patient Education and Counseling: 2001, 43(1), 4

tasks of health care providers. These tasks are carried out by means of verbal and non-verbal communication and apply as much to primary [6 and 7], secondary [8 and 9] and nursing care [10 and 11].

It has been demonstrated that physician's communication has a direct and strong relationship to peer-reviewed quality of care [12]. Research findings also show that the quality of provider-patient communication has an impact on patient satisfaction [13 and 14], adherence to prescriptions and advice [15], prevention of somatic fixation [16], referral and prescription rates [17], the recognition of mental disorders [18 and 19], and diminishing of malpractice suits [20]. With respect to providers' communication style a relationship was also found between better communication skills and a reduction of the level of psychological distress and an improvement of patients' health and functional status [17 and 21]. Also interesting evidence has been found about the persistent influence of gender [22 and 23] and ethnicity [24] in provider-patient interaction, asking for diversity within protocolized care.

An ongoing comparative study in ten European countries (Belgium, Estonia, Germany, The Netherlands, Poland, Romania, Spain, Sweden, Switzerland, United Kingdom) coordinated by Nivel (one of the initiators of EACH) since 1996 showed that communication itself varies with the type of health care system that is prevalent in a country [25]. This large-scale study, based on over 5000 videotaped consultations has conclusively demonstrated the relevance of international collaboration and gives ample opportunity for further research. As a side-effect of this study, an international network of researchers in all collaborating countries has been established that meet on a regular basis to exchange ideas and experiences.

Another group of practitioners, teachers and researchers in Europe, working in close contact with AAPP (American Academy of Physician and Patient) participating in the AAPP facilitator training program, and in cooperation with the group around MITA (Medical Interview Teaching Association) in the UK and the other countries in the field found that there was a basis for developing a collaborating network in Europe. From the discussions between these groups the idea for a European Association for Communication in Healthcare has been developed and put into practice.

\section{AIMS AND OBJECTIVES}

The aim of the new society is to stimulate the growth of an active network of researchers and teachers. The objectives of EACH are:

1. Facilitating contacts by publishing regular updates of actual membership lists: names, addresses, interest profiles, personal literature lists, available teaching material, and so on.

2. The organisation of bi-annual international conferences

The first international conference on Communication in Medicine took place in Oxford in 1996. Since then two European conferences were held on the same theme; in 1998 in Amsterdam [26] and in 2000 in Barcelona [1]. In 1999 a communication conference was held in Chicago [27]. Given the large number of participants from different disciplines, their high level of expertise, experience, knowledge and enthusiasm, the conferences were very successful. In addition, the fields of interest and background of the participants indicated the importance of incorporating both research and education.

3. The organisation of smaller scale workshops and meetings, e.g. on:

$\circ$ Teaching and 'teaching the teachers'

$\circ$ Research workshops (e.g. on methodology, observation schemes, etc.)

- International collaboration studies

○ Thematic workshops and symposia on educational topics (e.g. adult learning, medical students, teaching providers, skills lab and teaching teachers) and research topics (e.g. decision making, child issues, transcultural issues, ethics and communication, narrativity, empowerment, patient-centeredness and communication with somatizers).

4. The development of website 
Bensing, J., Dulmen, S. van, Kallerup, H., Visser, A., Borrell, F., Finset, A., Goedhuys, J., Langewitz, W., Mallinson, C., Peltenburg, M., Schofield, T., Zimmermann, C. The European Association for Communication in Healthcare. Patient Education and Counseling: 2001, 43(1), 4

The website should give an overview of relevant conferences and other meetings, reviews of new literature, a discussion platform for debate on actual issues, news from the society, and so on.5. Links with other relevant organisations

All over the world, the number of scientific associations is increasing rapidly. This indicates the need to co-operate and to exchange expertise and information. At the same time, however, this increase engenders the risk of fragmentation and discontinuity. Therefore, we strive at collaboration with already existing large networks and associations like WONCA (World Organisation of General Practitioners/Family Physicians) Region Europe ESFM/GP AAPP (American Academy of Physician and Patient), MITA and others.6. Affiliation with Patient Education and Counselling

It is important to have a distinguished journal, both for publishing our manuscripts (after the usual peer-reviewing process) and congress abstracts and exchanging news from the Association EACH. We are glad that Patient Education and Counselling has offered us interesting possibilities for a structural collaboration with $\mathrm{EACH}$.

\section{MEMBERSHIP}

We can offer a membership which includes the subscription of Patient Education and Counselling (which will also provide room for a regular News Letter) for 75 Euro. For more information on membership and subscription, please contact chairperson Jozien Bensing (j.bensing@nivel.nl) or secretary Sandra van Dulmen (s.vandulmen@nivel.nl).

\section{REFERENCES}

1. J.A. Hall and A. Visser, Health communication in the century of the patient. Patient Educ. Couns. 41 (2000), pp. 115-116.

2. Suchman A, Botelho R, Hinton-Walker P. Partnerships in Healthcare. Transforming relational process. University of Rochester, 1998.

3. H. Hollnagel and K. Malterud, Shifting attention from objective risk factors to patients' selfassessed health recources: a clinical model for general practice. Fam. Pract. 12 (1995), pp. 423-429.

4. I. Lunde, Patients' perceptions, a shift in medical perspective. Scand. J. Prim. Healthcare 11 (1993), pp. 98-104.

5. R.C. Smith, J.S. Lyles, J. Mettler, B.E. Stoffelmayr, L.F. van Egeren, A.A. Marshall, J.C. Gardiner, K.M. Maduschke, J.M. Stanley, G.G. Osborn, V. Shebroe and R.B. Greenbaum, The effectiveness of intensive training for residents in interviewing. A randomized, controlled study. Ann. Intern. Med. 2 (1998), pp. 118-126.

6. J.M. Bensing, K. Schreurs and A. de Rijk, The role of physician's affective behaviour in medical encounters. Psychol. Health 11 (1996), pp. 825-838.

7. Steine $S$, Finset $A$, Laerum E. A new questionnaire (PEQ) developed in primary health care for measuring patients' experience of interaction, emotion and counsultation outcome (submitted).

8. A.M. van Dulmen, Children's contribution to pediatric outpatient encounters. Pediatrics 102 (1998), pp. 563-568.

9. A.M. van Dulmen, Communication during gynecological outpatient consultations. J. Psychosom. Obstet. Gynecol. 20 (1999), pp. 119-126.

10. W.M.C.M. Caris-Verhallen, A. Kerkstra and J.M. Bensing, Nonverbal behaviour in nurseelderly patient communication. J. Adv. Nurs. 29 (1999), pp. 808-818.

11. I.P.M. Kruijver, A. Kerkstra, J.M. Bensing and H.B.M. van de Wiel, Nurse-patient communication in cancer care. Cancer Nursing 23 (2000), pp. 20-31.

12. J.M. Bensing, Doctor-patient communication and the quality of care. Soc. Sci. Med. 32 (1991), pp. 1301-1310.

13. A.M. van Dulmen, P.F.M. Verhaak and H.J.G. Bilo, Shifts in doctor-patient communication during a series of outpatient consultations in non-insulin-dependent diabetes mellitus. Patient Educ. Couns. 30 (1997), pp. 227-237.

14. J. Goedhuys, Correlates of the quality of doctor-patient communication. Patient Educ. Couns. 34 suppl. 1 (1998), p. S39. 
Bensing, J., Dulmen, S. van, Kallerup, H., Visser, A., Borrell, F., Finset, A., Goedhuys, J., Langewitz, W., Mallinson, C., Peltenburg, M., Schofield, T., Zimmermann, C. The European Association for Communication in Healthcare. Patient Education and Counseling: 2001, 43(1), 4

15. D.C. Bultman and B.L. Svarstad, Effects of physician communication style on client medication beliefs and adherence with antidepressant treatment. Patient Educ. Couns. 40 (2000), pp. 173-185.

16. P.F.M. Verhaak and M.A.R. Tijhuis, The somatizing patient in general practice. Int. J. Psychiat. Med. 24 (1994), pp. 157-177.

17. M. Stewart, J.B. Brown, A. Donner, I.R. McWhinney, J. Oates, W.W. Weston and J. Jordan, The impact of patient-centered care on outcomes. J. Fam. Pract. 49 (2000), pp. 796-804.

18. J.M. Bensing, J.J. Kerssens and M. Van de Pasch, Patient-directed gaze as a tool for discovering and handling psychosocial problems in general practive. J. Nonv. Behav. 19 (1995), pp. 223-242.

19. M. van de Pasch and P.F.M. Verhaak, Communication in general practice: recognition and treatment of mental illness. Patient Educ. Couns. 33 (1998), pp. 97-112.

20. W. Levinson, D.L. Roter, J.P. Mullooly, V.T. Dull and R.M. Frankel, Physician-patient communication. The relationship with malpractice claims among primary care physicians and surgeons. JAMA 277 (1997), pp. 553-559.

21. S.H. Kaplan, S. Greenfield and J.E. Ware, Assessing the effects of physician-patient interaction on the outcomes of chronic disease. Med. Care 27 (1989), pp. S110-S127.

22. A. van den Brink-Muinen, J.M. Bensing and J.J. Kerssens, Gender and communication style in general practice: differences between women's health care and regular health care. Med. Care 36 (1998), pp. 100-106.

23. A.M. van Dulmen and J.M. Bensing, Gender differences in gynecologist communication. Women Health 30 (2000), pp. 49-61.

24. L. Cooper-Patrick, J.J. Gallo, J.J. Gonzales, H.T. Vu, N.R. Powe, C. Nelson and D.E. Ford, Race, gender, and partnership in the patient-physician relationship. JAMA 282 (1999), pp. 583-589.

25. Brink-Muinen A van den, Verhaak PFM, Bensing JM, JM, Bahrs O, Deveugele M, Gask L, Mead N, Leiva-Fernandez F, Messerli-Rohrbach V, Oppizzi L, Peltenburg M, Perez A. The Eurocommunication study; an international comparative study in six European countries on doctor-patient communication in general practice. Utrecht, NIVEL, 1999.

26. P. Verhaak, Communication in health care. Patient Educ. Couns. 34 Suppl. 1 (1998), pp. S1-S82.

27. A. Visser and C.P. Herbert, Communication in medicine: a new impetus. Patient Educ. Couns. 38 (1999), pp. 1-2. 